\title{
Os senhores do tempo: a intervenção do bispado na procissão de Corpus Christi no século XVIII
}

Beatriz Catão Cruz Santos ${ }^{2}$

Depositário dos acontecimentos, lugar de potências e ações duráveis, lugar das ocasiões místicas, o quadro temporal adquire um interesse particular para quem quer que seja, deus, herói ou chefe, que queira triunfar, reinar, fundar: ele, quem quer que seja, deve tentar assenhorear-se do tempo, tal como do espaço. Georges Dumézil

O artigo analisa uma série recém-localizada de editais e pautas, emitidos pelo bispado entre 1759 e 1809 para a procissão de Corpus Christi da cidade do Rio de Janeiro, como meios de comunicação recorrentes entre o episcopado e a população. A partir desses documentos, sugere-se que a procissão constitui também um rito de separação no Antigo Regime e que os editais e as pautas são uma espécie de calendário ritual.

Palavras-chave: Corpus Christi, calendário, tempo.

The lords of the time: The intervention of the bishop's see on the 18th century Corpus Christi Procession

The article analyses a series of recently found edits and guidelines, issued by the bishop's see between 1759 and 1809 for the Corpus Christi procession in Rio de Janeiro, as well as means of communication resorted to between the episcopate and the people. It is sug-

1 Artigo recebido em 2.11.2011 e aprovado para publicação em 27.3.2012.

2 Professora doutora da Universidade Federal do Rio de Janeiro. 
gested that the procession establishes also a separation rite on the Old Regime, and that the edits and guidelines are a sort of ritual calendar.

Keywords: Corpus Christi, calendar, time.

\section{Les seigneurs du temps: l'intervention de l'évêché dans la procession de Corpus Christi au XVIIIe siècle}

L’article analyse une série d'édits et de registres, découverts il y a peu et émis par l'évêché de 1759 à 1809, pour la procession de Corpus Christi dans la ville de Rio de Janeiro, comme moyens de communication récurrents entre l'épiscopat et la population. Il semblerait que ces documents soient un type de calendrier rituel et que la procession constitue aussi un rite de séparation dans l’Ancien Régime.

Mots-clés: Corpus Christi, calendrier, temps.

Vários historiadores que analisaram a festa de Corpus Christi vêm sublinhando o papel dessa festa religiosa na constituição de uma unidade política. ${ }^{3} \mathrm{Na}$ época moderna e, particularmente, no reino português e seus domínios, a festa é comumente caracterizada pela solenidade, que pode ser aferida pela intervenção das autoridades leigas e religiosas no assunto e pelo investimento mobilizado pelas Câmaras de Lisboa e de cidades da América, Ásia e África Portuguesa. ${ }^{4}$

Em O Corpo de Deus na América, ${ }^{5}$ abordei a festa religiosa e a cerimônia da Monarquia portuguesa, considerando a procissão como seu ponto alto, ocasião em que os diversos corpos sociais desfilavam sob uma ordem hierárquica e naturalmente organizada. ${ }^{6}$ Nessa primeira interpretação, foram destacados os

3 RUBIN, Miri. La Fête Dieu. Naissance et dévélopement d'une célébration médiévale. In: MOLINIE, Antoinette (Org.). Le Corps de Dieu en fêtes. Paris: Les Éditions du Cerf, 1996; GRUZINSKY, Serge. "La Fête-Dieu à Mexico au temps da la Nouvelle-Espagne". Idem, Ibidem. p. 137-157; SANTOS, Beatriz Catão Cruz. The Feast of Corpus Christi: artisan crafts and skilled trades in eighteenth-century Rio de Janeiro. The Americas: A Quarterly Review of Inter-American Cultural History, v. 65, p. 215-216, 2008; MONOD, Paul Kleber. The power of kings: monarchy and religion in Europe 1589-1715. Yale University Press, 1999. p. 88.

4 BOXER, Charles Ralph. Portuguese society in the tropics: the municipal Councils of Goa, Macao, Bahia e Luanda. 1510-1800. Madison: University of Wisconsin Press, 1965. p. 144.

5 SANTOS, Beatriz Catão Cruz. O Corpo de Deus na América: a procissão de Corpus Christi nas cidades da América Portuguesa - século XVIII. São Paulo: Annablume, 2005.

6 Para uma discussão sobre a categoria de ordem no Antigo Regime português, consultar: HESPANHA, António Manuel. Imbecillitas. As bem-aventuranças da inferioridade nas sociedades do Antigo Regime. São Paulo: Annablume, 2010. p. 47-67. HESPANHA, António Manuel. A ordem. In: Imbecillitas. As bem-aventuranças da inferioridade nas sociedades do Antigo Regime. São Paulo: 
aspectos de agregação e aglutinação, em parte produzidos pela regulamentação que incidia sobre o evento social conformando uma espécie de communitas de cristãos e portugueses. ${ }^{7}$ As Câmaras eram responsáveis pelo enquadramento de espaço-tempo da festa e procissão - que, na prática, significava seu anúncio público, a nomeação dos que segurariam as varas do pálio, a indicação do acompanhamento, a determinação da limpeza das ruas e do trajeto da procissão. Enfim, a festa constituía um terreno para a unidade e, simultaneamente, para a diversidade no Império português, seja pela ação dos vereadores, seja pela intervenção de outros agentes e grupos no rito. Como elemento para contribuir para a diversidade, pode-se evocar a presença das corporações e/ou irmandades de ofício, ${ }^{8}$ que tinham papel ativo e estatutariamente definido no esplendor do cortejo, sobre as quais tenho investigado nos últimos anos, a começar pela Irmandade de São Jorge, mas também pela Irmandade de São José, a Irmandade de São Crispim e São Crispiniano e tantas outras no caso do Rio de Janeiro.

Se Corpus Christi contribuía para a unidade político-religiosa, a participação e a intervenção dos oficiais mecânicos com sua feição autônoma na vida urbana dificilmente expressariam uma estrutura de autoridade monolítica. ${ }^{9}$ Nesse sentido, faz-se necessário explorar mais os aspectos disjuntivos da procissão, reco-

Annablume, 2010. p. 47-67. Neste capítulo, que apresenta uma excelente síntese da categoria, o autor demonstra o peso do relato da Criação, entre outros textos e tradições, na cosmovisão e nas práticas sociais do mundo cristão e português. Nesse sentido, a narrativa da Criação tem um papel estruturante, sendo evocada para explicar o universo natural e humano e, inclusive, justificar as hierarquias entre os homens.

7 TURNER, Victor. O processo ritual: estrutura e antiestrutura. Petrópolis: Vozes, 1974. p. 116-159; SANTOS, Beatriz Catão Cruz. O Corpo de Deus na América: a procissão de Corpus Christi nas cidades da América Portuguesa - século XVIII. Op. cit.

8 É possível consultar o que defino por irmandades de ofício em: SANTOS, Beatriz Catão Cruz. Irmandades, oficiais mecânicos e cidadania no Rio de Janeiro do século XVIII. Varia Historia, Belo Horizonte, v. 26, p. 131-153, 2010; Catolicismo, cor e governança da terra no Rio de Janeiro no século XVIII. In: SAMPAIO, Antonio Carlos Jucá; FRAGOSO, João (Org.). Monarquia pluricontinental e a governança da terra no ultramar atlântico luso: séculos XVI-XVIII. Rio de Janeiro: Mauad X, 2012, p. 141-163. Consultar também trabalho que dá continuidade à abordagem e ao conceito que propus: SIQUEIRA, Mariana Nastari. Entre o signo da mudança e a força da tradição: o conflito entre a irmandade de S. Crispim e S. Crispiniano dos sapateiros e a Câmara, Rio de Janeiro, c. 1764c. 1821. Dissertação (Mestrado em História) - Universidade Federal Rural do Rio de Janeiro, Rio de Janeiro, 2011.

9 Para uma abordagem que reconhece a intervenção múltipla de poderes na festa: SANCHIS, Pierre. A caminhada ritual. Religião e Sociedade, n. 9, p. 15-26, jun. 1983. 
nhecendo-os não como casos isolados ou conjunturais, mas como dados constitutivos de um evento social que era regulamentado pela administração central, local e pelos poderes episcopais.

Trabalhos anteriores indicaram as ausências e os conflitos jurídicos desencadeados por conta da participação compulsória e da precedência na procissão; as fontes registram inúmeras "faltas", os pareceres médicos para justificá-las, "delitos", "desordens" e "escândalos" realizados por homens de diferentes status.Em 1743, por exemplo, o provedor da Fazenda Francisco de Siqueira Cordovil teria persuadido os cavaleiros das ordens militares a não comparecer à procissão do Corpo de Deus do Rio de Janeiro, "atropelando a ordem e o lugar em que sempre foram", e ainda

insistiu na temeridade de ver passar a procissão de sua janela, e sentado em uma cadeira contra a ordem do Reverendo Bispo e Censuras nela cominadas, desprezando as advertências por parte dos oficiais eclesiásticos se lhe fizeram para que se retirasse e proferindo palavras irreverentes contra as mesmas ordens.

Como analisei anteriormente, o caso tinha um precedente desencadeado pela iniciativa do mesmo provedor em construir um puxado sobre a Casa dos Contos para si e sua mãe. ${ }^{10} \mathrm{O}$ ponto nodal do novo conflito advinha do fato de que sua posição revertia a hierarquia entre clero e cavaleiros e punha em xeque um sentido comunitário, ainda que compulsório, em uma das festas reais mais importantes do calendário público-religioso do Império português. A negativa de participar no lugar devido da procissão, assistir da janela - como prescreviam as Constituições Primeiras do Arcebispado da Bahia, entre outras normas eclesiásticas - e incitar à desordem era ainda mais grave, por se tratar de uma autoridade pública, que deveria exercer um papel especular. Recentemente localizei um novo registro sobre esse conflito. ${ }^{11}$ Trata-se de uma carta do secretário de Estado

10 SANTOS, Beatriz Catão Cruz. O Corpo de Deus na América: a procissão de Corpus Christi nas cidades da América Portuguesa - século XVIII. Op. cit., p. 158-168.

11 Diz-se novo registro para diferenciar da correspondência consultada no Arquivo Histórico Ultramarino por ocasião da elaboração do livro. Trata-se de uma carta do secretário de Estado Marcos Antônio de Azeredo Coutinho ao bispo do Rio de Janeiro. O documento está em estado muito precário, impedindo a identificação precisa da norma gerada a partir do caso, que deveria incidir sobre a procissão. "Carta do Secretário de estado da Corte que escreveo ao senhor Bispo em resposta da representação que fez a majestade da desatenção que se fizerão os cavaleiros das ordens militares em dia da procissão do Corpo de Deus sendo o causador e provedor da fasenda". Lisboa, 4 abr. 1743. ACMRJ, Cod. E-278, Ordens régias 1681-1809. 
Marcos Antônio de Azeredo Coutinho ao bispo do Rio de Janeiro. O documento não traz grandes novidades, mas enfatiza que o conflito gerou muitos papéis correspondências, consultas e norma jurídica. Ele reforça o "escândalo" causado pelo provedor, a expectativa dos cavaleiros em vir depois do clero, subvertendo a ordem dos editais, que expressava uma ordem cósmica.

Podemos também lembrar o caso dos dois irmãos de São Jorge no Rio de Janeiro, oficiais mecânicos que foram processados e punidos entre 1773 e 1774 pela ausência na procissão. De acordo com os compromissos da irmandade (1757, 1790), cabia-lhes "compor a imagem de São Jorge", seu estado e ocupar posição de destaque no cortejo, o que era cobrado pela instituição e pela Câmara, que tinha a prerrogativa da punição. ${ }^{12}$

Como observou o historiador Stuart Schwartz, ${ }^{13}$ as faltas dos mestres de ofícios eram recorrentes em Salvador na segunda metade do século XVIII. Eles preferiam desfilar nas procissões cívicas como irmãos da Misericórdia a acompanhar as bandeiras de seus ofícios ao lado dos pobres e malvestidos jornaleiros. Na interpretação do historiador, essa era apenas uma das evidências da crescente diferenciação social em uma sociedade hierárquica e escravista. A decisão dos mestres de ofícios é contemporânea ao mal-estar registrado por diversas autoridades em relação à presença da "plebe", da "ralé", termos pejorativos utilizados para se referirem aos negros e mulatos que circulavam nas ruas da cidade, coparticipando nas festas reais. Lembremos que estas eram patrocinadas e organizadas pela Câmara, que exercia papel ambíguo ao representar a lealdade à Monarquia, ao rei e, simultaneamente, à República, cujos moradores eram convocados a participar.

Conflitos ocorridos nas festas de Corpus Christi também servem para refletir sobre como os discursos, as atitudes e os comportamentos eram modelados pela ordem teológico-política católica. Em "Representações da cidade de Salvador", João Adolfo Hansen propõe a interpretação das atas e cartas da Câmara de Sal-

12 Para uma análise mais detida desse caso: SANTOS, Beatriz Catão Cruz. O Corpo de Deus na América: a procissão de Corpus Christi nas cidades da América Portuguesa - século XVIII. Op. cit., p. 89-91. Pode-se encontrar uma análise comparativa dos dois compromissos mencionados no corpo do texto em: SANTOS, Beatriz Catão Cruz. The feast of Corpus Christi: artisan crafts and skilled trades in eighteenth-century Rio de Janeiro. The Americas: A Quarterly Review of Inter-American Cultural History, v. 65, p. 193-216, 2008.

13 SCHWARTZ, Stuart. Ceremonies of public authority in a colonial capital. The king's processions and the hierarquies of power in the seventeenth century Salvador. Anais de História de Além-mar, v. V, p. 7-26, 2004. 
vador na segunda metade do século XVII para tratar das convenções simbólicas também históricas que compõem a representação do "corpo místico" nas representações desse período, evitando deliberadamente a reconstituição da "realidade histórica da Bahia do século XVII" ${ }^{14}$ Com isso, lida com as categorias retóricas e teológico-políticas que modelam a representação, seja na edificação da cidade, seja na autodefinição dos vereadores como fidalgos ou ainda no protocolo das festividades. ${ }^{15}$ De acordo com Hansen,

em uma carta de julho de 1643, a Câmara pede providências ao rei, relatando "[...] o excesso e a insolência do Bispo Dom Pedro da Silva”. Segundo a Câmara, no dia de Corpus Christi de 1643, Dom Pedro saiu para o adro da Sé à frente da procissão sem esperar que a Câmara chegasse para acompanhá-la "como é costume". Segundo a Câmara, o bispo não esperou haver músicos na Sé, nem "gente de qualidade como convinha" para levar o pálio, apesar de o deão e outras pessoas eclesiásticas o terem advertido. A Câmara afirma que o bispo fez "tudo de propósito": "[...] tomando o Senhor nas mãos saiu tão antecipadamente e escandalosamente que fez força com a pouca gente para sair a Procissão". O governador chegou atrasado e, quando buscava a cabeça da procissão para ocupar seu lugar, o bispo não o esperou, entrando pela rua Direita. Aí, depois de largar a imagem do Senhor, saiu do pálio, largando a Custódia do chantre, "com admiração de todo o povo". Aproximando-se de um "homem de representação" que tinha sido vereador no ano anterior, o bispo o empurrou, ordenando-lhe que fosse adiante com o guião, o estandarte da Câmara. $\mathrm{O}$ vereador não lhe obedeceu imediatamente e o bispo o ameaçou em altas vozes com a excomunhão. Conforme a Câmara, o bispo o "[...] fez ir assim intimidado para onde iam as bandeiras e insígnias das mecânicas afrontosa e escandalosamente". Segundo a carta, toda a população de Salvador testemunhou o evento; por isso mesmo, o governador e a Câmara se portaram " [...] com toda a prudência e dissimulação para não se alterar o povo, e romper em outro sucesso que julgava merecia o seu" ${ }^{16}$

Como é possível observar, no conflito registrado pela Câmara, a autoridade eclesiástica rompe com o protocolo devido na festividade. No entanto, dada a ampla audiência do evento, a Câmara, apesar de insultada em sua honra, decide

14 HANSEN, João Adolfo. Representações da cidade de Salvador no século XVII. Sibila. Poesia e Cultura. Disponível em: <http://www.sibila.com.br/index.php/mapa-da-lingua/941-representacoes-da-cidade-de-salvador-no-seculo-xvii\#77>. Acesso em: 8 jul. 2010.

15 Segundo João Adolfo Hansen: “'Representação’ é uma categoria histórica substancialista ou a forma cultural específica da 'política católica' portuguesa que estrutura as práticas discursivas e não discursivas nesse tempo." O desenvolvimento dessa definição encontra-se em: "Representações da cidade de Salvador", p. 1 ss.

16 Id. Ibid. 
evitar um mal maior, a murmuração do povo. Nos autores dos séculos XVI e XVII, a prudência era uma das primeiras virtudes políticas, porque continha uma "arquitetônica do futuro", e a dissimulação, uma categoria aparentada. O próprio Hansen recupera a observação de Edward Maser, editor contemporâneo da Iconologia, de Cesare Ripa (c. 1560-c. 1622), segundo o qual a figura da Prudência tem duas faces, "porque o prudente olha à sua frente e para atrás, isto é, está atento aos fatos do passado relacionados a uma decisão a ser tomada e está ciente de seus possíveis resultados ou consequências do futuro". ${ }^{17}$ Diz-se que a dissimulação é uma categoria aparentada, porque é "uma técnica básica de ocultar ou adiar a verdade, mas não produzir a mentira". ${ }^{18}$ No caso, era uma dissimulação honesta, termos contraditórios em nosso mundo pós-iluminista, ${ }^{19}$ mas ade-

17 MASER, Edward. Cesare Ripas's baroque and rococo. Pictorial imagery. Nova York: Dover, 1971 apud HANSEN, João Adolfo; PÉCORA. Antônio Alcir Bernárdez. Glossário de categorias do século XVII, p. 8. Cesare Ripa (c. 1560, Perúgia - c. 1622, Roma) foi um filósofo que trabalhou para o cardeal Anton Maria Salviati como cozinheiro e mordomo. Após a morte do cardeal, Ripa trabalhou para seus parentes e tornou-se cavaleiro com o sucesso de seu livro Iconologia. Iconologia overo descrittione dell'imagini universali cavate dall'Antichità et da altri luoghi foi uma obra muito influente, baseada em representações emblemáticas egípcias, gregas e romanas. Era utilizado por oradores, artistas e poetas para dar substância a qualidades como virtudes, vícios, paixões, artes e ciências. Os conceitos eram organizados em ordem alfabética, desde a moda do Renascimento. Para cada um, havia uma descrição da figura alegórica proposta por Ripa para dar corpo ao conceito, atribuindo o tipo e a cor de sua roupa e seus atributos simbólicos variados, acompanhados da razão de sua escolha, razões geralmente baseadas na literatura, em grande parte clássica. A primeira edição de Iconologia é de 1593, dedicada a Anton Maria Salviati, e a segunda é de 1603. Há outras versões posteriores dos séculos XVIII e XIX. O livro é extremamente influente nos séculos XVII e XVIII, sendo citado extensivamente por várias formas artísticas. MASER, Edward. Baroque and Rococo Pictorial Imagery: the 1758-60 Hertel edition of Ripa's "Iconologia" with 200 engraved illustrations. Nova York: Dover, 1991. p. xiii-xix.

18 HANSEN, João Adolfo; PÉCORA. Antônio Alcir Bernárdez. Glossário de categorias do século XVII, p. 5.

19 Para refletir sobre as mudanças históricas que deram origem ao conceito contemporâneo de ritual, consultar o texto "Toward a genealogy of the concept of ritual", de Talal Asad. Nele, o autor reconhece a tensão que emerge no Renascimento, entre o comportamento interno e externo da pessoa, a reconceptualização do apropriado comportamento em direção a representações e habilidades na manipulação de representações, crescentemente divorciadas de um programa de formação do eu virtuoso, tal como se observava na Idade Média. E reflete sobre os efeitos dessas mudanças sobre o conceito e práticas rituais cristãs em um mundo crescentemente descristianizado. ASAD, Talal. Toward a genealogy of the concept of ritual. Genealogies of the religion; discipline and reasons of power in the christianity and Islam. Baltimore: Johns Hopkins University Press, 1993. p. 55-79. Segundo o autor, a partir do Renascimento, o comportamento apropriado adquire o status de tática, torna-se objeto de teorização não no campo da virtude, mas do poder. É por essa razão que Talal 
quados a uma perspectiva católica e contrarreformista e à decisão dos vereadores cuja finalidade previa o bem comum da República.

\section{A intervenção do bispado do Rio de Janeiro no século XVIII}

Hoje, proponho-me interpretar uma série recém-localizada de editais e pautas para a procissão de Corpus Christi da cidade do Rio de Janeiro emitidas pelo bispado entre 1759 e $1809 .{ }^{20}$ Esses editais e pautas constituíam formas de comunicação recorrentes entre o bispado e a população e fornecem dados sobre a intervenção do bispado na procissão que até o momento não foram alvo de análise. Antes de iniciar a análise pormenorizada, quero indicar duas hipóteses elaboradas a partir da seleção e leitura dessas fontes: em primeiro lugar, os editais e as pautas para a festa permitem entrever que a festa de Corpus Christi constitui também um rito de separação ${ }^{21}$ no Rio de Janeiro do Antigo Regime. Como procurarei demonstrar, eles dispõem os moradores da cidade em uma ordem tripartida e hierárquica e, ao mesmo tempo, sublinham distinções, especialmente entre clero e leigo. Em segundo lugar, os editais e as pautas ${ }^{22}$ podem ser considerados uma forma de calendário, de intervenção do poder religioso no tempo.

Asad extrai a sua reflexão, a meu ver, de autores que pensam a política - Bacon, Maquiavel -, a dança cortesã em conexão com os rituais religiosos.

20 ACMRJ, E-236 - 1742/1838 - Pastorais e Editais. A transcrição da maior parte dos editais e das pautas que uso neste texto foi realizada por Pablo Hernandez (bolsista de iniciação científica - Faperj) e Thainá Moura (bolsista de iniciação científica - Pibic/UFRJ). Procedi à atualização da grafia para facilitar a compreensão.

21 A expressão é utilizada por DAMATTA, Roberto. Carnavais, malandros e heróis: para uma sociologia do dilema brasileiro. Rio de Janeiro: Zahar, 1978. p. 144. Ela serve para qualificar a expressão "você sabe com quem está falando?" analisada pelo cientista social no texto "Você sabe com quem está falando? Um ensaio sobre indivíduo e pessoa no Brasil" (1978). Para DaMatta, o uso dessa expressão constitui um rito de autoridade, de separação, de afastamento, que remete à força dos referentes pessoais na sociedade brasileira. No artigo, o autor também contribui para uma abordagem mais geral das festas/rituais: o pressuposto de que os rituais constituem uma porta de entrada privilegiada para a compreensão das sociedades humanas. Quero crer que a ideia de rito de separação para qualificar a festa de Corpus Christi no mundo português do Antigo Regime sugere que a festa também aponta para a diferenciação acentuada das categorias sociais. Essa abordagem para refletir sobre as festas também se pode localizar em VALERI, Valerio. Festa. In: Enciclopédia Einaud., Lisboa: Imprensa Nacional/Casa da Moeda, 1994. v. 30, p. 40.

22 Estou fazendo referência sobretudo aos editais e às pautas, mas selecionei outros tipos de documentos para compor a reflexão deste texto, que fazem parte do códice. ACMRJ, E-236 1742/1838 - Pastorais e Editais. 
Evidentemente, há disposições sobre o espaço a ser percorrido pela procissão, a exemplo da menção em todos os anos a seu roteiro circular, que "há de sair da Nossa Igreja Catedral, encaminhando-se pela Rua do Rosário até a esquina da antiga dos Ourives voltará sobre o lado direito, e continuará o giro pelas ruas costumadas, e se recolherá a mesma Nossa Catedral". ${ }^{23}$ Mesmo sem esgotar a polissemia do termo giro, chama a atenção o fato de que a procissão que fecha o ciclo festivo católico se caracterize no espaço por uma volta, um circuito, à diferença, por exemplo, da procissão de São Sebastião que vigorava no século XVIII e que traçava uma linha em direção a antiga Igreja de São Sebastião situada no Morro do Castelo. ${ }^{24}$

Essa disposição sobre o espaço, que se repete até 1807, informa sobre o uso efetivo da Igreja de Nossa Senhora do Rosário e São Benedito como catedral. ${ }^{25}$ Lembremos que, desde que a Sé foi deslocada da Igreja de São Sebastião no antigo Morro do Castelo em função do crescimento da cidade em direção à várzea, ficou aquela como templo interino, ou seja, entre 1703 e 1808, quando passaria a ocupar a igreja dos frades carmelitas, tornada pelo alvará de 15 de junho simultaneamente catedral e capela real ou, para utilizar o termo do bispado, Santa Basílica Catedral Imperial Capela. ${ }^{26}$ A princípio, aventou-se a Igreja de São José, depois foi

23 Pode-se consultar a repetição nos seguintes editais: 1759, 1771, 1775, 1776, 1777, 1779, 1802, 1804, 1805, 1809. ACMRJ, E-236 - 1742/1838 - Pastorais e Editais (grifo meu).

24 Para os significados coevos de giro, consultar: BLUTEAU, Raphael. Vocabulario portuguez e latino. Coimbra: Collegio das Artes da Companhia de Jesu, 1712-1728; SILVA, Antônio de Morais. Diccionario da lingua portugueza. Lisboa: Typographia Lacerdina, 1813. As observações comparativas entre a procissão de Corpus Christi e São Sebastião que se apresentam no corpo do texto foram suscitadas pela análise comparativa de Maria Laura Viveiros de Castro Cavalcanti de dois festivais populares contemporâneos - o desfile das escolas de samba no carnaval carioca e os bois-bumbás de Parintins: CAVALCANTI. Maria Laura Viveiros de Castro. Os sentidos no espetáculo. Revista de Antropologia, São Paulo: USP, XV. v. 45, n. 1, p. 37-80, 2002.

25 A data de 1807 é indicativa, pois o edital desse ano apenas confirma o edital de 1775, que menciona o trajeto da procissão que parte da Rua do Rosário. Em 1809, localizamos uma alteração no trajeto, que parte da nova catedral. ACMRJ, E-236 - 1742/1838 - Pastorais e Editais.

26 O título é empregado no edital de 1809: ACMRJ, E-236 - 1742/1838 - Pastorais e Editais. Faço uso também do trabalho de Moreira de Azevedo para a história da Sé do Rio de Janeiro: AZEVEDO, Moreira de. O Rio de Janeiro, sua história, monumentos, homens notáveis, usos e curiosidades. Rio de Janeiro: Garnier, 1877. v. 1, p. 49-71. A data 1703, no corpo do texto, faz referência à carta régia dirigida à Câmara em que o monarca considerava a demanda do bispo de mudança da sé da Igreja de São Sebastião para a Igreja de São José, instruindo aos vereadores a sondar os custos com o novo edifício. 
transferida à de Santa Cruz dos Militares e, em 1737, à Igreja de Nossa Senhora do Rosário e São Benedito. Esta não acolheu o cabido com boa vontade, afinal, os irmãos que edificaram o templo do Rosário tinham a memória de conflitos entre seus confrades e o cabido eclesiástico na década de 30 do século XVII, quando a Sé ainda ocupava a Igreja de São Sebastião, onde eles nasceram e se abrigavam. A partir do relato de Moreira de Azevedo, pode-se dizer que a interinidade de mais de um século da Sé advinha não apenas dos vultosos recursos, necessários à construção de uma nova Sé, que mobilizavam o erário régio e as doações locais de leigos e eclesiásticos. Ela resultava também dos conflitos desencadeados pela transferência que envolveram o cabido, os homens bons da cidade, os confrades de Santa Cruz, os de Nossa Senhora do Rosário e São Benedito, o governador e o monarca. Em 3 de outubro 1739, o rei D. João V expede uma provisão em que responde negativamente à representação dos irmãos do Rosário, ordenando que se conservasse interinamente na

igreja do Rosário o cabido e catedral, enquanto se fazia nova sé, para cuja obra recomendava de novo se escolhesse sítio próprio onde se executasse, sem ser na igreja dos pretos, por não ser decente que o mesmo prelado e o cabido estivessem celebrando os ofícios divinos em uma igreja emprestada, e de mistura com os pretos. ${ }^{27}$

Nessa ocasião, a partir de negociações entre o bispo, o governador Gomes Freire de Andrade e o brigadeiro José Fernandes Pinto Alpoim, permaneceu a Sé no Rosário e se deu início ao planejamento da praça, nomeada Largo da Sé Nova, posteriormente de São Francisco de Paula, para abrigar o novo templo. Em 1748, a pedra fundamental do edifício foi celebrada com a presença do "bispo, câmara, nobreza e povo" ${ }^{28}$ e a construção chegou a ostentar a seta e a flecha, emblemas alusivos ao santo padroeiro da cidade e orago do templo. No entanto, em fins da década de 90 do século XVIII, as obras foram novamente suspensas e nessa praça surgiriam outros edifícios, como a Escola Politécnica. O fato é que Nossa Senhora do Rosário e São Benedito permanece Sé interina por mais de 70 anos e, a despeito das restrições expressas pelo monarca em relação à Igreja dos Pretos, recebe os bispos D. Frei Antonio do Desterro, D. José Joaquim Justiniano e D. José Caetano e a família real de Bragança em março de 1808. Nesse ponto, é interessante

27 AZEVEDO, Moreira de. Op. cit., p. 53.

28 A disposição desses corpos ou status sociais é aquela apresentada por Moreira de Azevedo, que atualiza a ordem do Antigo Regime. Id. Ibid. 
fazer menção à posição tomada por D. Frei Antonio do Desterro (1694-1773) em seu testamento. A despeito das leis régias testamentárias que então limitavam o poder dos testadores em legar seus bens para instituições religiosas, institui como sua herdeira universal a Fábrica da Sé Catedral desse bispado, e "sendo esta do padroado régio e tão necessitada e pobre, como é notório não pode deixar de ser do agrado do dito senhor [o soberano] esta instituição”. Faleceu sem ver concluída a nova catedral, mas legou a sua herdeira principal os rendimentos provenientes da Fazenda do Rio Comprido, que lhe pertencia e que incluía escravos, feitores, além de terras e sítios aforados. ${ }^{29}$

Também é possível observar a interferência do bispado nos domínios particulares, para além das disposições sobre o espaço a ser percorrido pela procissão, pois, segundo os editais, "terá cada pessoa no que lhe pertencer as ruas limpas e alcatifadas de Flores, Ramos e ervas cheirosas, e as janelas, e fronteiras das casas ornadas com sedas e tapeçarias no melhor modo possível". ${ }^{30}$

Em meu entendimento, salta aos olhos o controle do tempo pelo bispado. Como observa Jacques Le Goff, a intervenção dos detentores do poder na medida do tempo é um elemento essencial de seu poder, e apenas os detentores carismáticos do poder são senhores do calendário. ${ }^{31}$ Nesse ponto, pode-se lembrar que carisma, antes de se tornar um termo usado e abusado pelo senso comum e pelas ciências sociais, deriva da teologia cristã e que remete justamente àqueles capacitados pelos poderes de Deus para operar milagres. ${ }^{32}$

Os editais e as pautas para a procissão do Rio de Janeiro são documentos manuscritos, seriais e ordenados cronologicamente entre 1759 e 1809. Ambos incluem correções e repetições perceptíveis por conta das rasuras. ${ }^{33}$ É interessante

29 OSB, Monacais IV, liv. 2, Cod. 24, D. Frei Antonio do Desterro. O testamento é de 3 de maio de 1773. Sobre as leis testamentárias no contexto das reformas pombalinas: RODRIGUES, Cláudia. As leis testamentárias de 1765 e 1769 no contexto das "reformas pombalinas" no mundo luso-brasileiro. Disponível em: <http://www.encontro2008.rj.anpuh.org/resources/content/anais/1212772170_ARQUIVO_ Asleistestamentariasde1765e1769-CLAUDIARODRIGUES.pdf>. Acesso em: 20 out. 2011.

30 Disposições como essa podem ser encontradas nos editais: ACMRJ, E-236 - 1742/1838 - Pastorais e Editais.

31 LE GOFF, Jacques. Calendário. In: História e memória. Campinas: Unicamp, 1990. p. 420.

32 GEERTZ, Clifford. Center, dings, and charisma: reflections on the symbolics of power. In: Local knowledge: further essays in interpretive anthropology. Nova York: Basic Books, 2000. p. 120-123.

33 Para consultar correções e repetições, remeto ao Edital que S. Exa. Rma. foi servido mandar passar para a Procissão do Corpo de Deus, de 30 de maio de 1771. Em 27 de maio de 1809, 
também observar a possibilidade de identificar quem escreve o documento, ou seja, o escrivão da câmara eclesiástica, a serviço do governo da diocese na ocasião. Também é onipresente à referência ao direito, como prerrogativa das corporações, que são mencionadas nos editais e identificadas mais detalhadamente nas pautas. A exemplo do trecho do edital de 1771, ano para o qual localizamos a pauta correspondente.

E porque estão obrigados a acompanhar esta procissão não só todo o Clero, mas também os Cavaleiros das Ordens Militares, as Comunidades, Irmandades, e Confrarias desta Cidade, e não queremos que nessa concorrência destas e daqueles se exercitem dúvidas, e controvérsias em ato tão solene a respeito de preferências. Mandamos que todos e cada um vão no lugar, que lhe destinamos no Edital, ou Pauta, que para este fim mandamos expedir assinado por nós e sem que essa Nossa Determinação possa em algum tempo prejudicar o direito que lhes competir. ${ }^{34}$

Algumas das características desses documentos tornam-se mais evidentes quando comparamos a série de pautas aos exemplares impressos para a procissão do Corpo de Deus de Lisboa. ${ }^{35}$ Para falar das semelhanças, tanto em Lisboa quanto no Rio de Janeiro, faz-se referência ao direito dos particulares - "E a precedência que regulamos nesta pauta a cada uma nas referidas corporações se entenderá sem prejuízo do direito que competir"36 pode ser interpretada como

serão passados editais para as quatro freguesias dessa cidade, e juntamente pautas das irmandades, comunidades, cavaleiros e clero para a procissão do Corpo de Deus na forma abaixo registrada. ACCMRJ, E-236 - 1742/1838.

34 ACCMRJ, E-236 - 1742/1838 (grifos meus).

35 ANTT, Cx 523, doc. 8509. Tabella da Solemne procissão do Corpo de Deus de Lisboa Ocidental, e forma como hão de ir as Irmandades, Comunidades e Clero. Anno de 1717; Tabella da Solemne procissão do Corpo de Deus de Lisboa, e forma como hão de ir as Irmandades, Comunidades e Clero. Anno de 1743; BNL, Códice 158, Tabella da Solemne Procissão do Corpo de Deus de Lisboa Occidental e forma com que hão de ir as cruzes das confrarias, irmandades, comunidades regulares e clero. 1723. BUC, Miscelânea 683. Tabella da Solemne procissão do Corpo de Deus de Lisboa, e forma como hão de ir as Irmandades, Comunidades e Clero. Anno de 1755. Tabella da Solemne procissão do Corpo de Deus de Lisboa, e forma como hão de ir as Irmandades, Comunidades e Clero. Anno de 1779.

36 O trecho é extraído da pauta de 1772. A de 1771 apresenta teor semelhante, mas não cita literalmente a relação entre direito e corporações, por isso optei por citar a de 1772, pertencentes ao bispado de D. Frei Antonio do Desterro. ACCMRJ, E-236 - 1742/1838, Tabela da Solemne Procissao do Corpo de Deus desta cidade do Rio de Janeiro; e forma com que hão de hir as Confrarias, e Irmandades, Comunidades, Cavaleiros e Clero, anno de 1771; Pauta da procissão solene de Corpus Christi desta cidade do Rio de Janeiro, e forma como hao de ir as confrarias, irmandades, comunidades, cavaleiros e clero, ano 1772. 
uma fórmula de reconhecer e prevenir disputas de precedências, que sabemos recorrentes.

No entanto, a remissão ao direito na citação pode ser interpretada na chave de António Manuel Hespanha, para quem o sistema jurídico do Antigo Regime apresentava espaços de abertura e indeterminação provenientes do próprio direito comum. Nesse sentido, a autonomia do direito colonial investigada pelo autor $^{37}$ decorria da capacidade de preencher os tais espaços de abertura, e não da existência de leis próprias. Entre os fatores que favoreciam essa autonomia do direito estava a convivência de diversas ordens jurídicas - o direito comum, o direito canônico e os direitos dos reinos -, ou seja, um pluralismo de direitos, característica básica da sociedade europeia medieval e moderna, que funciona como ponto de partida para sua diferenciação potencializada, segundo o autor, nas situações "de fronteira", como as colônias. No caso que analisamos, importa sublinhar que entre os fatores de autonomia e particularização do direito na ordem jurídica do Antigo Regime estava o modelo de relação entre o direito geral e o particular, que favorecia o último, a exemplo das normas que protegiam os estatutos das comunas, cidades ou municípios; as que protegiam o costume ou o regime de privilégios. ${ }^{38}$ Nesse sentido, a repetição da mensagem "sem prejuízo do direito que competir" em editais e pautas de Corpus Christi além e aquém-mar expressa o reconhecimento por parte do bispado da convivência de jurisdições e o primado das corporações, com seus estatutos e privilégios.

Nessa linha de reflexão sobre os fundamentos da ordem social, pode-se ainda acrescentar que os editais e as pautas de Corpus Christi, entre outros documentos que formam o códice analisado, funcionam como “interfaces de vulgarização’ por meio das quais os textos-matriz sobre a religião, a natureza [e a sociedade] obtinham traduções adequadas a uma grande multiplicidade de auditórios" ${ }^{39}$

37 HESPANHA, António Manuel. Por que é que existe e em que consiste um direito colonial brasileiro. 2005, p. 1-11. Disponível em: <http://www.metajus.com.br/textos-estrangeiro/DireitoComumeDireitoColonial.pdf $>$.

38 Depois de exemplificar as ordens jurídicas particulares, António Manuel Hespanha discorre sobre seu poder na relação com o direito comum do reino e com a ordem da natureza: "Em todos estes casos, ainda que as normas particulares não pudessem valer contra o direito comum do reino enquanto manifestação de um poder político, podiam derrogá-lo enquanto manifestação de um direito especial, válido no âmbito da jurisdição dos corpos de que provinham.” Id. Ibid.

39 A ideia, que reproduzo no corpo do texto, é de António Manuel Hespanha para falar da permanência e da difusão da cultura jurídica no Antigo Regime no âmbito do senso comum. Nesse 
Como observei, os editais e as pautas eram formas de comunicação entre o bispado e a população. No conjunto, partiam do bispo para os fiéis, e no período selecionado referem-se ao governo da diocese por três deles: Antonio do Desterro (1747-1773), José Joaquim Justiniano Mascarenhas Castelo Branco (1774-1805) e José Caetano da Silva Coutinho (1808-1833). O edital, como lhe é próprio e informa, era divulgado aos moradores por meio de sua fixação em local público da catedral no primeiro dia de preceito. Não seria demasiado lembrar que os éditos dos bispos não são os únicos, mas ora concorrem, ora complementam aqueles realizados pelos vereadores do Senado da Câmara, instituição responsável pelo enquadramento espaçotemporal da festa. Os editais do bispado tinham como principais destinatários os religiosos, embora postulassem a presença na procissão de todo o clero, dos cavaleiros das ordens militares, das comunidades, das irmandades e das confrarias. Em todos os editais consultados, faz-se referência ao lugar destinado a cada ordem ou estado, mas a mensagem mais dura destina-se aos clérigos de ordens baixas e menores da cidade e de seu subúrbio. Segundo o texto:

Os não tiverem legítimo impedimento, mandamos com pena de excomunhão maior ipso facto incurrenda e de dez tostões de multas aplicados para a Fábrica da Nossa Sé, se acharem no sobredito dia por seis horas da manhã na mesma Catedral, e acompanhem a Procissão até se recolher. E se acharão presentes as ditas horas com hábito, e tonsura decente, sobrepeliz lavadas, barbas e Coroas feitas. ${ }^{40}$

Clérigos de ordens baixas e menores devem ser entendidos à diferença dos leigos, mas também no interior da hierarquia dos clérigos. Os menores tinham sido recém-admitidos - cerca de meio ou um ano - nas ordens menores, provavelmente por meio da imposição do bispo e uma bênção. A categoria inclui acólito, exorcista, leitor, porteiro, salmista e chantre. Distinguem-se das ordens maiores, que receberam o sacerdotium, um sacramento, e compreendem exclu-

sentido, o autor indica que os ambientes institucionais em que os textos jurídicos e teológicos eram produzidos dispunham de "interfaces de vulgarização", que ele elenca: a parenética, a confissão auricular, a literatura de devoção, a liturgia, a iconologia sagrada, para a teologia; as fórmulas notariais, a literatura de divulgação jurídica, os brocados e as decisões dos tribunais, para o direito. HESPANHA, António Manuel. Imbecillitas. As bem-aventuranças da inferioridade nas sociedades do Antigo Regime, p. 38-39.

40 ACCMRJ, E-236 - 1742/1838, Edital que S. Exa. Rma. foi servido mandar passar para a Procissão do Corpo de Deus, de 30 de maio de 1771. 
sivamente o padre (ou presbítero) e o bispo. Os clérigos de ordens sacras eram o subdiácono e o diácono, que só constituíam o ministerium. Para simplificar, pode-se dizer, grosso modo, que a mensagem era mais dura, porque se dirigia aos seminaristas, ${ }^{41}$ que poderiam vir a se tornar os pastores, que, à diferença dos leigos, suas ovelhas, tinham como função primeira a gestão dos assuntos religiosos na Igreja. Portanto, é a partir da localização dessa categoria existente na cidade do Rio de Janeiro que devemos entender a convocação dos seminaristas, cujo não comparecimento implicaria multa e excomunhão. A excomunhão, no século XVIII e inícios do XIX, era a última pena eclesiástica, gravíssima, que implicava uma ampla privação: o destinatário era impedido de usar os sacramentos e ofícios religiosos e, ainda, de se comunicar com os fiéis. $\mathrm{O}$ castigo de cunho religioso, consequentemente, os privaria de várias formas de intercurso social - o comércio, as honras, as dignidades -, porque os tornava infamados. ${ }^{42}$ Como sinalizou Marcel Mauss, ${ }^{43}$ a negativa em participar da dádiva equivale a declarar guerra; é recusar a aliança e a comunhão. No caso da festa que ora analisamos, que atualiza o mistério da Eucaristia, ${ }^{44}$ trazia aos seminaristas a exclusão da comunidade de católicos.

41 O termo "seminarista", utilizado no corpo do texto, faz referência àquele que realizava formação para ingressar no clero, um estudante do seminário maior. Esse que não se confunde com os estudantes, os colegiais de maneira geral. Para uma história do Seminário de São José, instituição criada no espírito do Concílio de Trento: AZEVEDO, Moreira de. Op. cit., p. 349-354. Para uma breve história do ensino com ênfase em seus profissionais e público: CAVALCANTI, Nireu. O Rio de Janeiro setecentista: a vida e a construção da cidade da invasão francesa até a chegada da Corte. Rio de Janeiro: Jorge Zahar, 2004. p. 156-158. Nessa abordagem, que identifica as instituições religiosas, ou seja, o ensino fornecido pelas ordens, os seminários (São José, São Joaquim e Lapa do Desterro), e o fornecido pelos quartéis, reconhece-se a importância dos professores particulares e do ensino informal na educação do chamado período colonial.

42 Para o significado coevo de excomunhão, fiz uso das seguintes obras: BLUTEAU, Raphael. Vocabulario portuguez e latino. Coimbra: Collegio das Artes da Companhia de Jesus, 1712-1728; SILVA, Antônio de Morais. Diccionario da lingua portugueza. Lisboa: Typographia Lacerdina, 1813.

43 MAUSS, Marcel. Ensaio sobre a dádiva. Forma e razão da troca nas sociedades arcaicas (1924). In: Sociologia e antropologia. São Paulo: USP, 1974. p. 58.

44 Vale observar que o termo "eucaristia" (ação de graças e louvor) é um dos nomes, mas vem a se tornar o mais frequente e difundido no Ocidente e no Oriente, e "enquanto é sacramento' ('presença real') só se verifica no ato que celebra e atualiza o sacrifício de Cristo, isto é, torna presente o gesto do 'servo de Javé' que se oferece livremente como vítima pelos próprios irmãos". SATORE, Domenico; TRIACCA, Achille M. Dicionário de liturgia. São Paulo: Paulus, 1994. p. 395-415. Note-se que, para os cristãos, a dimensão de sacrifício contida na celebração eucarística, nessa interpretação, convive com a exaltação, a alegria do encontro com o Cristo depois da morte e a ressurreição. 
Os editais, como vimos, também prescreviam aos clérigos de ordens baixas e menores regras para uma dada aparência para a ocasião. Elas podem ser inseridas em um conjunto de disposições sobre os corpos das pessoas prescritas pelo poder pastoral para a procissão de Corpus Christi, como o impedimento de estar à janela ou sentado em cadeira durante sua passagem, o preceito de se ajoelhar com toda a reverência e submissão diante do Santíssimo Sacramento e a proibição de danças profanas, que aparece em alguns dos editais. ${ }^{45}$ Porém, essas disposições sobre os corpos só podem ser claramente interpretadas se tivermos em mente que alguns desses elementos, como o hábito, a barba e, sobretudo, a tonsura vêm se apresentando como distinções entre clérigos e leigos, que se construíram ao longo da história da cristandade. Desde a Idade Média,

o recebimento do hábito é um momento importante, pois as vestimentas litúrgicas distinguem o clero no interior da igreja. No exterior, os hábitos definem-se durante muito tempo negativamente: eles não devem apresentar comprimento, na cor, nos ornamentos, nenhuma das características das roupas laicas (desta forma, são proscritos os sapatos com laços ou a cor vermelha, em benefício do preto ou do azul). Mas é sobretudo a tonsura ou coroa cuidadosamente raspada no topo do crânio que distingue o clérigo na sua aparência corporal; ela contrasta com a cabeleira frequen-

A dimensão do sacrifício, que corresponde à compulsória gratidão dos fiéis nos cultos eucarísticos (que inclui a festa do corpo de Deus), está expressa em documentos contemporâneos: "[...] a instrução Eucharisticum mysterium, no $\mathrm{n}^{\circ}$ 50, afirma: 'os fiéis, quando veneram Cristo presente no Sacramento, devem lembrar-se de que esta presença provém do sacrifício e tende à comunhão, sacramental e espiritual ao mesmo tempo. A piedade, portanto, que estimula os fiéis a se prostrarem diante da santa eucaristia, os atrai a participar mais profundamente do mistério pascal e $a$ corresponder com gratidão ao dom daquele que, com sua humanidade, infunde incessantemente a vida divina nos membros de seu corpo [...]"'. Id. Ibid., p. 414 (grifo meu). Para uma história da festa de Corpus Christi entre a Idade Média e a Época Moderna: RUBIN, Miri. Op. cit. No artigo, Miri Rubin, uma medievalista, se desloca da ênfase sobre a Bula de Urbano IV em 1264, que institui a universalização da festa, para a análise do contexto em que surge a festividade, marcado pela presença de uma espiritualidade leiga e feminina. Para acesso ao trabalho integral da mesma autora: Corpus Christi: the eucaristic in late medieval culture. Cambridge, 1994.

45 Para uma discussão sobre a exclusão de elementos populares - figuras, danças, gigantes e representações - fornecidos pelos oficiais mecânicos à festa e procissão de Corpus Christi, no século XVIII: SANTOS, Beatriz Catão Cruz. O Corpo de Deus na América: a procissão de Corpus Christi nas cidades da América Portuguesa - século XVIII, p. 110-144. O caráter profano das danças, a meu ver, pode ser pensado à diferença e na relação com o sagrado, cuja definição é móvel e vária historicamente, tal como expressou Roberto DaMatta na apresentação da obra de Arnold Van Gennep: Os ritos de passagem, estudo sistemático dos ritos de porta e da soleira, da hospitalidade, da adoção, gravidez e parto, nascimento, infância, puberdade, iniciação, ordenação, coroação, noivado, casamento, funerais, estações, etc. Petrópolis: Vozes, 2011. p. 16. 
temente longa dos leigos (em particular dos nobres), e também com a tonsura muito mais ampla dos monges. Clérigos e monges são glabros [imberbes] [...]. ${ }^{46}$

Lembra ainda Jean-Claude Schmitt que “a tonsura dos clérigos é um sinal de reconhecimento que permite, se necessário, reivindicar um privilégio de foro, quer dizer, não depender da justiça comum [... ${ }^{\prime}{ }^{47}$ Pode-se dizer que hábito, tonsura e barbas prescritos aos seminaristas faziam parte do estado liminar ${ }^{48}$ em que se encontravam aqueles estudantes e representavam sinais para que fossem reconhecidos entre os moradores da cidade e adjacências.

Nos editais e nas pautas também fica evidenciada uma representação da sociedade fluminense que atualiza as três ordens e que se combina com outras distinções, como a indicada entre clérigos e leigos. Nada de se estranhar, pois o episcopado do Rio de Janeiro interpreta aquela sociedade por intermédio da antiga classificação indo-europeia de clero, nobreza e povo, critérios plásticos, que garantiram sua perpetuação nas sociedades europeias ou naquelas em que os europeus obtiveram hegemonia no período do Antigo Regime, ao menos como representação da sociedade continuamente reificada. Nas procissões de Corpus Christi, que podem ser definidas como cerimônias de informação, ${ }^{49}$ os papéis convocatórios - ou seja, editais e pautas - espelham aquela ordem.

Nos editais, as três ordens são apenas indicadas, embora especificadas: o clero se subdivide - "Ordens sacras e menores" ${ }^{0}$-, assim como os membros do terceiro estado, em irmandades e confrarias. Há certo reforço dos diferentes status e instituições da cidade, referidos de forma genérica como "corporações". As pautas, por outro lado, complementam os editais, ${ }^{51}$ pois reforçam certas mensagens, como as regras de precedência, os direitos dos particulares, e identificam, nomeiam, se não a totalidade, a maior parte das instituições e grupos existentes

46 SCHMITT, Jean-Claude. Clérigos e leigos. In: LE GOFF, Jacques; SCHMITT, Jean-Claude. Dicionário temático do Ocidente medieval. São Paulo: Edusc, 2006. p. 242.

47 Id. Ibid.

48 Para a definição de limiaridade, em que o caso do noviço é referido como um dos exemplos: TURNER, Victor. Op. cit., p. 116-159.

49 A expressão aponta para enunciações públicas do tema da autoridade, como indicou FOGEL, Michèle. Les cérémonies de l'information dans la France du XVIe au milieu du XVIIIe siècle. Paris, 1989 apud MONOD, Paul Kleber. Op. cit., p. 83.

50 As ordens estão inclusas nas "comunidades", no caso das pautas. ACCMRJ, E-236 - 1742/1838.

51 A função de complementaridade das pautas é indicada pelos próprios editais. Id. Ibid. 
na cidade naquele ano. A partir das pautas ou tabelas, pode-se dizer que, no Rio de Janeiro de 1771, participavam da procissão cerca de 24 irmandades, distribuídas pelas quatro freguesias da cidade, sete comunidades - que incluíam as ordens regulares, as ordens terceiras e os Meninos Órfãos -, os Cavaleiros das Ordens Militares e o clero secular. Vale observar que, entre os regulares mencionados nas pautas entre 1771 e 1809, estavam presentes somente os carmelitas, os franciscanos, os capuchinhos italianos e os beneditinos, visto que os jesuítas haviam sido expulsos de Portugal e seus domínios em 1759. Na segunda metade do século XVIII, que coincide com o ministério pombalino, tentou-se não só apagar o peso da presença dos jesuítas nas missões indígenas, no ensino, mas era necessário para os bispados, em sua maioria cooptados pelas reformas, riscar a presença dos jesuítas no ritual que descrevia a ordem social. ${ }^{52}$ É possível localizar a presença de documentos do acervo diocesano para o mesmo período, que tratam da desapropriação de bens imóveis que pertenciam à Companhia de Jesus, assim como uma pastoral, que advertia os súditos de não se comunicarem com os jesuítas, em função de sua conjuração contra a real pessoa. ${ }^{53}$

Entre as ordens terceiras, são indicadas nas pautas a Ordem Terceira de São Francisco de Paula, a Ordem Terceira de Nossa Senhora do Carmo e a Ordem Terceira de São Francisco, que vinham incorporadas às regulares e em uma ordem de crescente antiguidade, visto que a de São Francisco de Paula era a mais recente, tendo sido instituída na diocese de D. Frei Antonio do Desterro. ${ }^{54}$

52 Para uma discussão geral e informativa sobre as reformas no reino e na América Portuguesa: MAXWELL, Kenneth Marques de Pombal: paradoxo do Iluminismo. São Paulo: Paz e Terra, 1996. p. 95-117. Para uma breve discussão sobre a eficácia da ação da política pombalina, marcada pelo regalismo, sobre as ordens religiosas com ênfase na Ordem do Carmo: SILVA, Leandro Ferreira Lima da. Entre a teoria e a prática: eficácia e resistência na ação regalista sobre os carmelitas do Rio de Janeiro (1750-1808). Disponível em: <http://www.encontro2010.rj.anpuh.org/resources/ anais/8/1276734607_ARQUIVO_Artigocompleto_LeandroFerreiraLimadaSilva_USP_.pdf $>$. Acesso em: 2 out. 2011.

53 ACCMRJ, E-236 - 1742-1838 - Pastorais e Editais; 1809-1862 - E-279 - Ordens régias.

54 A informação da instituição da Ordem Terceira de São Francisco de Paula procede de uma pequena biografia feita pelos beneditinos: OSB, Monacais IV, liv. 2, Cod. 24, D. Frei Antonio do Desterro. Para uma história das ordens terceiras no Rio de Janeiro: MARTINS, William de Souza. Membros do corpo místico: ordens terceiras no Rio de Janeiro (c. 1700-1822). São Paulo: Edusp, 2009. 
Em 1809, seriam 26 irmandades e nove comunidades, indicando um ligeiro crescimento das formas associativas na cidade. ${ }^{55}$ Entre 1771 e 1776 , já se observam mudanças, mas, se compararmos a primeira pauta, de 1771, com a última, de 1809 , ficam evidenciados o surgimento, no período, de novas irmandades e o desaparecimento de outras. Por exemplo, na antiga freguesia da Sé, surgem as irmandades de Santo Antônio da Mouraria, São Gonçalo Garcia, Nossa Senhora das Mercês, Nossa Senhora do Rosário e São João Evangelista dos Solteiros, sendo as quatro primeiras reconhecidamente associações de pardos e/ou de pretos. ${ }^{56}$ No entanto, desaparece do registro a Irmandade de Nossa Senhora dos Passos. Há diversas alterações, algumas vinculadas à transformação da cidade em corte, com a vinda da família real: o surgimento da Santa Basílica Catedral Imperial Capela, a Irmandade da Real Capela, a menção ao provedor a substituir o bispo, o protocolo mais detalhado das vestimentas para os párocos na procissão, assim como a expansão das comunicações com a reprodução e o envio para as quatro freguesias da cidade, existentes desde o episcopado de D. Frei Antonio do Desterro. ${ }^{57}$

Em termos formais, a pauta de 1809 , a última manuscrita até então localizada, é simplificada. Torna-se uma listagem, mas a finalidade e a mensagem se mantêm: informar aos moradores que a ordem na procissão é de crescente importância social - das irmandades até o clero. Na dianteira da procissão, como de costume, as bandeiras dos ofícios e, para as diversas freguesias, uma precedência para suas irmandades, cujos critérios visíveis são o destaque dado ao Guião da Irmandade do Santíssimo Sacramento e à antiguidade de cada irmandade. Com isso, pode-se imaginar, além da hierarquia do conjunto do cortejo,

55 No caso das ordens terceiras, verificamos a indicação da Ordem Terceira de Nossa Senhora da Conceição do Hospício e dos religiosos da Terceira Ordem da Penitência, em posições não equivalentes de precedência. Pauta da procissão solemne de Corpo de Deus desta Corte do Rio de Janeiro, e forma com que hao de ir as Confrarias, Irmandades, Comunidades, Cavaleiros e Clero. Ano 1809. fl. 150 e 151. ACCMRJ, E-236 - 1742/1838.

56 Sobre essas irmandades, há uma vasta bibliografia. Indico apenas alguns títulos, em que se podem localizar especificamente algumas delas: MULVEY, Patrícia. The black lay brotherhoods of colonial Brasil: a history. Nova York, Ph.D., 1976. p. 318. Xerox University Microfilms. Ann Arbor, Michigan 88 108; KARASCH, Mary. A vida dos escravos no Rio de Janeiro (1808-1850). São Paulo: Cia. das Letras, 2000. p. 134; VIANA, Larissa O idioma da mestiçagem: as irmandades de pardos na América Portuguesa. Campinas: Unicamp, 2007.

57 Os dados apontados são extraídos dos editais e pautas, exceto sobre as quatro freguesias, que teriam sido estabelecidas por D. Frei Antonio do Desterro. ACCMRJ, E-236 - 1742/1838; OSB, Monacais IV, liv. 2, Cod. 24. 
que atualiza a ordem tripartida, um conjunto de alas, de menor hierarquia no interior dos estados.

Os editais, as pautas e as pastorais consultados ${ }^{58}$ no Arquivo da Cúria do Rio de Janeiro constituem uma espécie de calendário do bispado para a sociedade fluminense na segunda metade do século XVIII. Eles expressam uma tentativa dos bispos de controlar o tempo dos homens na diocese, como tivemos oportunidade de observar pelos assuntos abordados: editais para a procissão de Corpus Christi, de São Sebastião, a celebração do Patrocínio de Nossa Senhora, o dia de entrudo; pastorais sobre a compostura dos párocos, a proibição de comer carne, $o$ matrimônio e as formas de enterro dos escravos etc. Pastorais sobre enterro eram formas de controle dos ritos de passagem. Aliás, uma normalização dos assentos é atribuída a Frei Antonio do Desterro. ${ }^{59}$

Antonio do Desterro Malheiro era beneditino, tendo professado seus votos em 1711. Foi nomeado abade do mosteiro da Estrela (Portugal) em 1737, mas logo no ano seguinte tornou-se bispo de São Paulo de Luanda (Angola), ficando nesse cargo durante seis anos, quando foi transferido para o bispado do Rio de Janeiro. Na ocasião da morte do conde de Bobadela, ${ }^{60}$ fez parte do triunvirato que governou as capitanias do Rio de Janeiro, São Paulo e Minas. Em seu testamento, instrumento simultâneo de transmissão de bens e de bem morrer, menciona somente os períodos de episcopado, entre os ofícios de que ocupara. No testamento, o então bispo do Rio de Janeiro roga por um bom trespasse e pela sal-

58 ACCMRJ, E-236 - 1742/1838.

59 Há uma pequena biografia de Antonio do Desterro muito bem informada. Nesta, faz-se referência à normalização dos assentos de batismo, casamento e óbitos na diocese do Rio de Janeiro pelo bispo, cuja posse efetuou-se em 1747. Há indicação de pastoral de 30 de maio de 1742 a respeito dos assentos, portanto antes de seu governo. Também há outras pastorais durante seu governo, que devem estar relacionadas com o tratamento da questão, como a de 1748 , sobre o descuido dos párocos quanto a satisfazer as exigências fixadas pela Constituição do Arcebispado da Bahia, e a de 1753, proibindo o depósito ou sepultamento de cadáver sem conhecimento do pároco. CUNHA, A. Dioceses e bispos do Brasil. Revista do Instituto Histórico e Geográfico Brasileiro, Departamento de Imprensa Nacional, v. 222, p. 8-82, 1954. Há indicação breve das realizações de D. Frei Antonio do Desterro, classificadas em "empreendimentos", leiam-se edificações e liturgia, e em ações "espirituais”. OSB, Monacais IV, liv. 2, Cod. 24.

60 A referência utilizada no corpo do texto é título atribuído a Gomes Freire de Andrade (16851763) em 1758, que desempenhava as funções de governador da capitania do Rio de Janeiro. 
vação, pedindo a intercessão de inúmeros santos, mas manifesta especial devoção por S. Sebastião e Sant’Ana, referidos como os "padroeiros deste bispado". ${ }^{61}$

A análise das pautas e dos editais de Corpus Christi permitiu entrever que eles marcam os dias, os meses, os anos e até as horas dos moradores da cidade e de seu subúrbio. Ao comparar os editais, observamos que o início da procissão foi marcado sucessivamente às 10 , às 6 , às 7 e às 10 horas da manhã. A mudança de horário pode denotar alterações no ritmo citadino e/ou uma tentativa por parte das autoridades religiosas de introduzir um marco ritual, por intermédio de um dos sistemas mais abstratos de medida do tempo: a hora. ${ }^{62}$

As pautas e os editais de Corpus Christi eram calendários rituais, à semelhança dos que Georges Niangoran-Bouah encontrou em alguns povos africanos da atualidade, ou seja, forneciam as datas das festas e cerimônias, diziam das proibições rituais e eram "calendários falantes", cuja transmissão era escrupulosamente assegurada pelas autoridades. ${ }^{63}$ A documentação consultada também pode ser considerada como uma espécie de calendário ritual, porque separa, diferencia e ritma o tempo festivo do tempo do trabalho. Nesse sentido, pode-se fazer referência à Pastoral com que se dispensam alguns dias santos para se poder melhor trabalhar depois de ouvida a missa, documento que permite refletir de forma privilegiada sobre a dialética entre os dias festivos, santos e os dias de trabalho. Segundo esse documento, era preciso que a Igreja se posicionasse diante da "multiplicidade dos dias festivos" - que obrigavam "os Artífices, os Jornaleiros e a gente pobre das classes inferiores a transgredir o preceito de não trabalhar ou de querendo guardá-lo a privarem-se dos socorros necessários" - e da disposição, do gosto da "sociedade católica dos portugueses do Rio de Janeiro" pelos divertimentos, pelos "espetáculos públicos e mundanos”. ${ }^{64}$ A pastoral de D. José Caetano

61 OSB, Monacais IV, liv. 2, Cod. 24.

62 Como lembra Le Goff (Op. cit., p. 446): "O dia de vinte e quatro horas, que começa à meia-noite, a hora, não se difundiu ainda por toda parte. Para muitos povos (hebreus, muçulmanos, africanos etc.), o dia vai de um pôr do sol ao pôr do sol seguinte. Os calendários dos povos que adotaram o calendário juliano-gregoriano exibem ainda traços do corte que marca a passagem da luz às trevas e vice-versa: habitualmente vem indicada a hora a que o Sol se levanta e se põe. A civilização industrial não conseguiu ainda separar o dia de vinte e quatro horas do dia natural, com a sua dupla face de luz e sombra [...]"

63 NIANGORAN-BOUAH apud LE GOFF, Jacques. Op. cit., p. 423.

$64 \mathrm{Na}$ pastoral, indica-se a "música profana, a decoração pomposa, o luxo descomposto e a concorrência das mulheres" como atrativos para os moradores da cidade apresentarem-se nos templos 
parece apontar para uma concepção de tempo que prevalecia entre os ibéricos nos séculos XVI e XVII e que para o bispo urgia reformar. ${ }^{65}$

Segundo Gilberto Freyre, ${ }^{66}$ os ibéricos, descobridores e navegadores pioneiros, detinham um sentido de espaço mais avançado e científico que a maior parte dos europeus de então. No entanto, sua concepção de tempo, se comparada aos europeus do Norte, era "arcaica" ou "tradicional", desvinculada do tempo cronometrado, marcado pelo relógio. Em seu entendimento, isso explicaria em parte o fato de espanhóis e portugueses não terem concluído o processo de modernização, mas teria trazido vantagens de caráter psicossocial e cultural, facilitando a formação de uma civilização criativa em áreas não europeias e o contato, a interpenetração entre as culturas. Hoje, a bibliografia já problematizou o suposto pioneirismo ibérico, assim como o elogio da colonização, ${ }^{67}$ mas vale reter a ideia de que o tempo entre os ibéricos católicos estaria desde muito definido não pelo ritmo constantemente progressivo, pelo trabalho contínuo, que só se interrompe aos domingos - dia dedicado ao descanso -, mas pela muita alternância entre trabalho e lazer, labor e dança, propiciado pela própria Igreja. Era um tempo em

católicos. Como lazeres, são mencionadas "as partidas de jogo, de dança, os espetáculos públicos, os divertimentos mundanos e os teatros”. ACCMRJ, E-236 - 1742/1838.

65 FREYRE, Gilberto. On the Iberian concept of time. In: O brasileiro entre outros hispanos: afinidades, contrastes e possíveis futuros nas suas inter-relações. Rio de Janeiro: José Olympio, 1975. p. 132-144. Fiz uso da discussão de Gilberto Freyre em: SANTOS, Beatriz Catão Cruz. A festa de São Gonçalo na viagem em cartas de La Barbinais. Via Spiritus, Porto, n. 11, p. 221-238, 2004. Maria Laura Cavalcanti (Op. cit.) também retoma a interpretação de Gilberto Freyre sobre a noção de tempo dos ibéricos, atenta "às consequências sociológicas da existência em ato de certa noção de tempo". Ela parte da versão católica do cristianismo na configuração da cultura popular brasileira e dos significados cosmológicos do bumbá de Parintins e do carnaval carioca, festas profanas inscritas no calendário cristão católico. Para uma discussão que correlaciona concepções de tempo associadas a práticas religiosas e trabalho no Brasil do século XVI, é importante consultar o trabalho de Rossana G. Britto (A saga de Pero do Campo Coutinho, o primeiro processo da inquisição no Brasil. Petrópolis: Vozes, 2000. p. 121-125). Nele, a autora analisa o processo inquisitorial movido contra o donatário Pero do Campo Coutinho, que não observava os dias santos e falava em mudar a data de Corpus Christi, seguindo uma lógica colonizadora que deslegitimava a intervenção religiosa no mundo do trabalho.

66 FREYRE, Gilberto. Op. cit.

67 Seguem os autores que põem em questão o pioneirismo ibérico e o elogio da colonização portuguesa, respectivamente: ARAÚJO, Ricardo Benzaquen de. Guerra e paz; Casa-grande \& senzala e a obra de Gilberto Freyre nos anos 30. Rio de Janeiro: Ed. 34, 1994; THOMAZ, Luís Felipe. De Ceuta a Timor. Lisboa: Difel, 1994. p. 1-41. 
que os rituais de renovação da vida tinham lugar de destaque, um tempo a serviço do próprio homem.

Como o próprio título insinua, a pastoral de D. José Caetano da Silva Coutinho permite, a partir daquela data, 8 de agosto de 1811, "perpetuamente para o futuro [...] licita e livremente todos os nossos Diocesanos de qualquer Estado e condição que sejam, ocupar-se nas obras servis e mecânicas ou exerçam qualquer espécie de trabalho corporal nos dias santos", contanto que assistam previamente à missa. A pastoral elenca os dias de dispensa do bispado e, particularmente, os da cidade do Rio de Janeiro. ${ }^{68}$ Seus moradores deveriam guardar, além dos dias prescritos, o oitavo dia de São Sebastião (27 de janeiro) e o dia de São Januário (19 de setembro). A história dos santos patronos citadinos concorrentes ao Rio de Janeiro ainda está aberta a investigação, mas sabemos que São Sebastião é comemorado no dia 20 desde o século XVI, sendo em 1733 instituída procissão em honra ao santo na oitava, enquanto São Januário torna-se dia de guarda em $1710 .{ }^{69}$

A pastoral de D. José Caetano também reforça o caráter sagrado dos domingos e responsabiliza a "sociedade abastada da ordem superior", "sociedade católica dos portugueses do Rio de Janeiro" por ousar profanar os dias festivos seja mantendo abertas as oficinas, as casas de comércio e ativas as obras temporais, seja dedicando-se aos divertimentos, seja obrigando "os Artífices, os Jornaleiros e a gente pobre das classes inferiores" e os escravos a "transgredir o preceito de não trabalhar".

Os domingos, sobre os quais a pastoral discorre longamente, estão entre os

68 Segundo a pastoral, os dias dispensados para o conjunto do bispado eram: o dia de São Matias a 24 ou 25 de fevereiro, a segunda oitava de Páscoa, o dia de São Felipe e Santiago em $1^{\circ}$ de maio, a Invenção da Santa Cruz em 3 de maio, a segunda oitava do Espírito Santo, o dia de São Lourenço a 10 de agosto, o dia de São Bartolomeu a 24 de agosto, o dia de São Mateus a 21 de setembro, o dia de São Miguel a 29 de setembro, o dia de São Simão e São Judas a 28 de outubro, o dia de Santo André a 30 de novembro, o dia de São Tomé a 21 de dezembro, o dia de São José Evangelista a 27 de dezembro, o dia dos Santos Inocentes a 28 de dezembro, o dia de São Silvestre a 31 de dezembro. ACMRJ, E-236 -1742/1838 - Pastorais e Editais.

69 Segundo Pizarro, data de 19 de novembro de 1710 o edital que declarou o dia de São Januário (19 de setembro) dia santo e de guarda: ARAÚJO, José de Souza Azevedo Pizarro e. Memórias históricas do Rio de Janeiro e províncias anexas... Rio de Janeiro: Typographia de Silva Porto, 1822. t. IV, p. 84. Para uma análise do culto de São Sebastião na cidade do Rio de Janeiro: CARDOSO, Vinicius Miranda. Emblema sagitado: os jesuítas e o patrocinium de São Sebastião no Rio de Janeiro, sécs. XVI- XVII. Dissertação (Mestrado em História) - Universidade Federal Rural do Rio de Janeiro, 2010. Sobre a procissão de São Sebastião: "carta régia de 14 de novembro de 1733". ANRJ, Cód. 952 - Cartas régias, provisões, alvarás e avisos - 48 v., 1662-1801. 
dias, que não estão propriamente no poder e na livre disposição do Homem porque o Senhor Nosso Deus os tem dedicado ao seu especial serviço eterno mandando aos seus servos, que trabalhem e empreguem nas obras do Espírito e nos cuidados do Céu estas pequenas porções de um largo tempo. ${ }^{70}$

Como é possível observar nessa pastoral de inícios do século XIX, a redução dos dias santos é simultânea ao reforço da santificação do domingo, como dia em que o fiel deve dedicar-se a outra ordem de trabalhos: "as esmolas, os bons exemplos de virtude, e todas as obras de edificação e piedade", dia de "ações de graças", de "homenagens, adoração, sacrifícios" para com o Criador. Os domingos são "pequenas porções de um largo tempo" prenhes de memória cristã, a exemplo da Criação e da Ressurreição. Nesse caso, vale lembrar que, no relato da Criação (Gênese), o sétimo dia, o último da semana, é o dia do descanso de Deus, tema retomado pela pastoral, que cita o profeta Ezequiel (Ezequiel, 20) para lembrar a justiça divina aplicada àqueles que violavam seus "sábados e dias de festa”. Nesse ponto, a pastoral articula uma dada relação entre a Criação e a ordem social católica e escravista no Brasil e, particularmente, no Rio de Janeiro, assim como nos faz lembrar que os dias de repouso nas grandes religiões monoteístas não são coincidentes. $^{71}$

Como é possível que uns semelhantes dias se vejam esquecidos, desprezados, profanados entre homens que professam a Fé do Evangelho num País Católico numa sociedade de Portugueses na Cidade do Rio de Janeiro? Como é possível que nestes dias se vejam abertas as Oficinas, patentes as Casas de Comércio, continuado o estrondo das obras; e as fadigas dos Obreiros, empregados os homens nas suas ocupações e as mulheres com suas tarefas ordinárias e respirando todos o amor, e o espírito do século, desconhecendo outro empenho e outro destino, e mostrando nos cuidados, nos gestos, nas palavras, que este mundo é a sua pátria e que seu Deus é o lucro e o interesse? ${ }^{72}$

Com uma linguagem persuasiva e ameaçadora, a pastoral de D. José Caetano da Silva Coutinho questiona as ações, o comportamento dos "homens que pro-

70 ACMRJ, E-236 - 1742/1838 - Pastorais e Editais.

71 "Os hebreus tinham estabelecido o sábado como dia de repouso e mantiveram este repouso do shabbãt, que vai do pôr do sol de sexta-feira até o dia seguinte. Os cristãos escolheram o domingo para dia de repouso, dia da ressurreição de Cristo. Os muçulmanos anteciparam-no para sexta-feira, e começa ao pôr do sol de quinta-feira." LE GOFF, Jacques. Op. cit.

72 ACMRJ, E-236 - 1742/1838 - Pastorais e Editais. 
fessam a Fé do Evangelho", movidos tão somente pelo "espírito do século", pelo "lucro" e pelo "interesse". Como assinala em algumas passagens, os homens são fundamentalmente pecadores, e os dias santos são "sinais da Misericórdia Divina", "toques de Sua Graça" que cabe ao homem observar e aproveitar. ${ }^{73}$

A pastoral do então bispo e capelão-mor articulava tempos diversos, a partir de referências bíblicas e crísticas, citava Deus e o Demônio ${ }^{74}$ e termina por ceder, de forma peculiar, ao "espírito do século":75 determinava a ampliação do

73 Os homens, como categoria genérica associada à humanidade, são definidos como "desgraçados filhos de Adam"; "perdidos mortais" na pastoral de D. José Caetano da Silva Coutinho ACMRJ, E-236 - 1742/1838 - Pastorais e Editais. Acreditamos que a concepção de homem manifestada por esse bispo, assim como seu posicionamento em relação ao poder monárquico português, possa ser, em parte, explicada pela influência do jansenismo em suas formulações. A despeito do caráter multiforme do movimento jansenista, há indicações que apontam para acusações de "louvar sumamente Nicole, Pascal, outros de Port Royal e Pavia e principalmente aprovar 'Praelectionum de Pedro Tambutini' e outros campeões do jansenismo italiano", quando José Caetano da Silva Coutinho era candidato ao bispado (CUNHA, A. Op. cit., p. 107-108). Nesse trabalho, há uma pequena biografia que indica os diversos ofícios ocupados no Império português e, posteriormente, Império do Brasil: bispo do Rio de Janeiro e capelão-mor (1808-1833); deputado à Constituinte e senador do Império.

$74 \mathrm{O}$ bispo faz referência aos que buscam apagar os dias festivos dedicados a honrar a Deus e, entre eles, em todos os tempos o "quase Demônio". Como observa Jean-Claude Schmitt ao analisar os ritos na cultura e sociedade medieval, a Igreja era a principal agência ritual e sua função era sobretudo a de garantir, por meio do clero, certo controle sobre as potências invisíveis que supostamente regiam o destino do mundo: Deus, os santos, o Diabo (Ritos. In: LE GOFF, Jacques; SCHMITT, Jean-Claude. Dicionário temático do Ocidente medieval. Bauru: Edusc, 2006. p. 415-130). A mesma observação pode ser aplicada ao contexto que estamos analisando, não esquecendo a multiplicação e consequente concorrência entre agências rituais no Rio de Janeiro da passagem do século XVIII para o XIX.

75 Ao analisar termos que definem unidades do calendário, Jacques Le Goff assinala a dupla acepção do termo século - romana e cristã - e observa que sua aplicação é bastante recente, datando do século XVIII. "A palavra latina saeculum era aplicada pelos romanos a períodos de duração variável, ligada muitas vezes à ideia de uma geração humana. Os cristãos, embora conservassem a palavra na sua antiga acepção, conferiram-lhe também o sentido derivado de vida humana, vida terrena, em oposição ao além. Mas, no século XVI, certos historiadores e eruditos tiveram a ideia de dividir os tempos em porções de cem anos. A unidade era bastante longa, a cifra 100 simples, a palavra conservava o prestígio do termo latino, e no entanto levou algum tempo a impor-se. O primeiro século em que verdadeiramente se aplicaram o conceito e a palavra foi o século XVIII: a partir daí, esta cômoda noção abstrata ia impor a sua tirania à história" (LE GOFF, Jacques. Op. cit., p. 452). Ainda com relação à noção de século, vale lembrar as reflexões de Koselleck sobre a Modernidade, inaugurada em fins do século XVIII e inícios do século XIX. De acordo com o historiador, século constitui um dos conceitos que apontam para a emergência e a percepção do período como "tempo novo". Para demonstrar em que medida século constitui um dos critérios históricos de temporalização, ao lado de aceleração, progresso indica como desde o século XVII, "os séculos passaram de 
tempo de trabalho e a diminuição do tempo festivo. Na pastoral, o bispo apreende a aceleração do tempo, as mudanças de sua historicidade e justifica a mudança de posição da Igreja, a começar pelos bispos de Portugal, que, nos "últimos tempos", liberaram os subalternos do preceito de não obrar nos dias festivos, para fazê-los trabalhar. Com a pastoral, um gênero veiculado aos diocesanos, lida em diversas missas, o bispo buscava assenhorear-se do tempo dos moradores do Rio de Janeiro.

Ao longo do texto, procurou-se demonstrar como os editais e as pautas de Corpus Christi, em conjunto com outros documentos analisados no códice do Arquivo Geral da Cidade do Rio de Janeiro, eram calendários rituais. Eles ritmavam e diferenciavam o tempo ordinário - do dia a dia, do trabalho - do tempo festivo, marcado pelos rituais do calendário cíclico e santoral. A análise da pastoral de 1811 deixou ainda mais evidente algo que pode ser identificado nos editais e nas pautas de Corpus Christi, lançados pelos bispos de D. Antonio do Desterro, D. José Joaquim Justiniano Mascarenhas Castelo Branco e D. José Caetano da Silva Coutinho: os dias festivos e, em particular, a festa-dádiva de Corpus Christi são ocasião em que a sociedade católica portuguesa do Rio de Janeiro devia reconhecer e retribuir a graça recebida de "Jesus Cristo Nosso Senhor, Redentor, e Criador do mundo". ${ }^{76}$

meras referências cronológico-aditivas de classificação para ordenar diacronicamente as múltiplas matérias simultâneas e adquirem pretensões históricas próprias. Passam a ser unidades coerentes e carregadas de sentido", "transformam-se em conceitos temporais da experiência histórica". KOSELLECK, Reinhart. Futuro passado: contribuição à semântica dos tempos históricos. Rio de Janeiro: Contraponto/PUC-Rio, 2006. p. 283-284; The eighteenth century as the beginning of modernity. In: The practice of conceptual history, timing history, spacing concepts. Stanford: Stanford University, 2002. p. 166.

76 A expressão aparece de maneira literal em: "Em 27 de maio de 1809 se passarão Editais para as quatro freguesias desta cidade, e juntamente pautas das irmandades, comunidades, cavaleiros e clero para a procissão do Corpo de Deus na forma abaixo registrada" (1809), mas o sentido é evocado em diversos documentos consultados. ACMRJ, E-236 - 1742/1838 - Pastorais e Editais. Tomamos como referência para a noção de dádiva e o caráter compulsório de dar, receber e retribuir o texto de MAUSS, Marcel. Op. cit. 